\title{
Bcl-2-Related Ovarian Killer Protein
}

National Cancer Institute

\section{Source}

National Cancer Institute. BCl-2-Related Ovarian Killer Protein. NCI Thesaurus. Code

C126579.

$\mathrm{Bcl}$-2-related ovarian killer protein $(212 \mathrm{aa}, \sim 23 \mathrm{kDa}$ ) is encoded by the human BOK gene.

This protein plays a role in the positive regulation of apoptosis. 